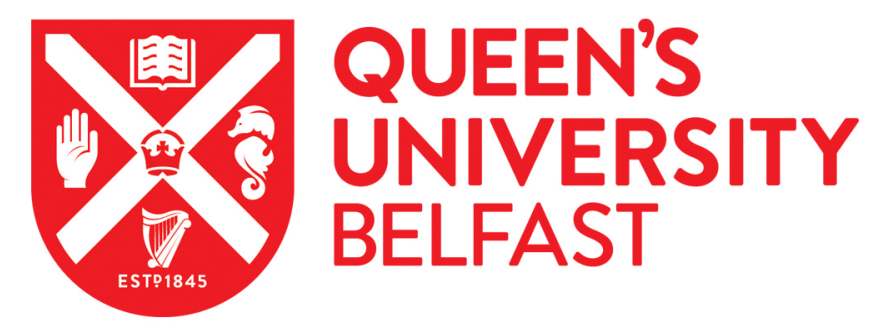

\title{
Late Holocene climatic changes in Tierra del Fuego based on multiproxy analyses of peat deposits
}

Mauquoy, D., Blaauw, M., Van Geel, B., Borromei, A., Quattrocchio, M., Chambers, F. M., \& Possnert, G. (2004). Late Holocene climatic changes in Tierra del Fuego based on multiproxy analyses of peat deposits. Quaternary Research, 61(2), 148-158. https://doi.org/10.1016/j.yqres.2003.10.001

Published in:

Quaternary Research

Document Version:

Publisher's PDF, also known as Version of record

Queen's University Belfast - Research Portal:

Link to publication record in Queen's University Belfast Research Portal

\footnotetext{
General rights

Copyright for the publications made accessible via the Queen's University Belfast Research Portal is retained by the author(s) and / or other copyright owners and it is a condition of accessing these publications that users recognise and abide by the legal requirements associated with these rights.
}

Take down policy

The Research Portal is Queen's institutional repository that provides access to Queen's research output. Every effort has been made to ensure that content in the Research Portal does not infringe any person's rights, or applicable UK laws. If you discover content in the Research Portal that you believe breaches copyright or violates any law, please contact openaccess@qub.ac.uk. 


\title{
Late Holocene climatic changes in Tierra del Fuego based on multiproxy analyses of peat deposits
}

\author{
Dmitri Mauquoy, ${ }^{\mathrm{a}, *}$ Maarten Blaauw, ${ }^{\mathrm{b}}$ Bas van Geel, ${ }^{\mathrm{b}}$ Ana Borromei, ${ }^{\mathrm{c}}$ Mirta Quattrocchio, ${ }^{\mathrm{c}}$ \\ Frank M. Chambers, ${ }^{\mathrm{d}}$ and Göran Possnert ${ }^{\mathrm{e}}$ \\ ${ }^{a}$ Palaeobiology Program, Department of Earth Sciences, Uppsala University, Villavägen 16, SE-752 36 Uppsala, Sweden \\ ${ }^{\mathrm{b}}$ Institute for Biodiversity and Ecosystem Dynamics, University of Amsterdam, Kruislaan 318, 1098 SM Amsterdam, The Netherlands \\ ${ }^{\mathrm{c}}$ Departamento de Geología, Universidad Nacional del Sur, San Juan 670 (8000), Bahía Blanca, Argentina \\ ${ }^{\mathrm{d}}$ Centre for Environmental Change and Quaternary Research, GEMRU, University of Gloucestershire, Cheltenham GL50 4AZ, UK \\ e Angström Laboratory, Division of Ion Physics, S-75121 Uppsala, Sweden
}

Received 11 February 2003

\begin{abstract}
A ca. 1400-yr record from a raised bog in Isla Grande, Tierra del Fuego, Argentina, registers climate fluctuations, including a Medieval Warm Period, although evidence for the 'Little Ice Age' is less clear. Changes in temperature and/or precipitation were inferred from plant macrofossils, pollen, fungal spores, testate amebae, and peat humification. The chronology was established using a ${ }^{14} \mathrm{C}$ wiggle-matching technique that provides improved age control for at least part of the record compared to other sites. These new data are presented and compared with other lines of evidence from the Southern and Northern Hemispheres. A period of low local water tables occurred in the bog between A.D. 960-1020, which may correspond to the Medieval Warm Period date range of A.D. 950-1045 generated from Northern Hemisphere tree-ring data. A period of cooler and/or wetter conditions was detected between ca. A.D. 1030 and 1100 and a later period of cooler/wetter conditions estimated at ca. cal A.D. 1800-1930, which may correspond to a cooling episode inferred from Law Dome, Antarctica.
\end{abstract}

(C) 2004 University of Washington. All rights reserved.

Keywords: Climate change; Tierra del Fuego; Sphagnum mires; ${ }^{14} \mathrm{C}$ wiggle-match dating; Medieval Warm Period; Little Ice Age

\section{Introduction}

Numerous paleoecological studies have described the late Quaternary climate and vegetation history of Tierra del Fuego and southern Patagonia (Ashworth et al., 1991; Borromei, 1995; Heusser, 1989, 1995, 1998; Markgraf, 1983, 1993; McCulloch and Davies, 2001; Pendall et al., 2001; Quattrocchio and Borromei, 1998; White et al., 1994), but to date the region lacks detailed plant macrofossil, testate amebae, and peat humification analyses (Barber et al., 1994; Charman et al., 1999; Mauquoy et al., 2002). Furthermore, no ${ }^{14} \mathrm{C}$ wiggle-match chronologies (Blaauw et al., 2003; Kilian et al., 1995) are currently available to establish the precise timing of local vegetation and potential climateinduced changes spanning the last ca. $1300 \mathrm{yr}$. This dating technique simply relies on the nonlinear relationship be-

\footnotetext{
* Corresponding author. Fax: +31-20-525-7832.

E-mail address: mauquoy@science.uva.nl (D. Mauquoy).
}

tween ${ }^{14} \mathrm{C}$ age and calendar age to match the shape of a sequence of closely spaced ${ }^{14} \mathrm{C}$ dates with the ${ }^{14} \mathrm{C}$ calibration curve in order to improve precision. This paper addresses the chronological shortcoming identified in the review of Rabassa et al. (2000), in combination with new multiproxy analyses of peat deposits exposed in peat works in the Valle de Andorra, located ca. $10 \mathrm{~km}$ to the northeast of Ushuaia, Tierra del Fuego, Argentina (S 54 ${ }^{\circ} 45^{\prime}$, W $68^{\circ} 18^{\prime}$, ca. $180 \mathrm{~m}$ asl, see Fig. 1).

\section{Materials and methods}

Peat monoliths of $1 \mathrm{~m}$ depth were collected from sections exposed in the peat works using metal boxes $(50 \times 15 \times 10$ $\mathrm{cm})$. Intact raised peat bogs ca. $1.5 \mathrm{~km}$ to the westnorthwest of the peat works were used for the collection of plant macrofossil type material and analyses of testate amebae from varying positions above local water tables (local water table depths spanned $0-101 \mathrm{~cm}, \mathrm{pH}$ range $4.72-6.05)$. The 


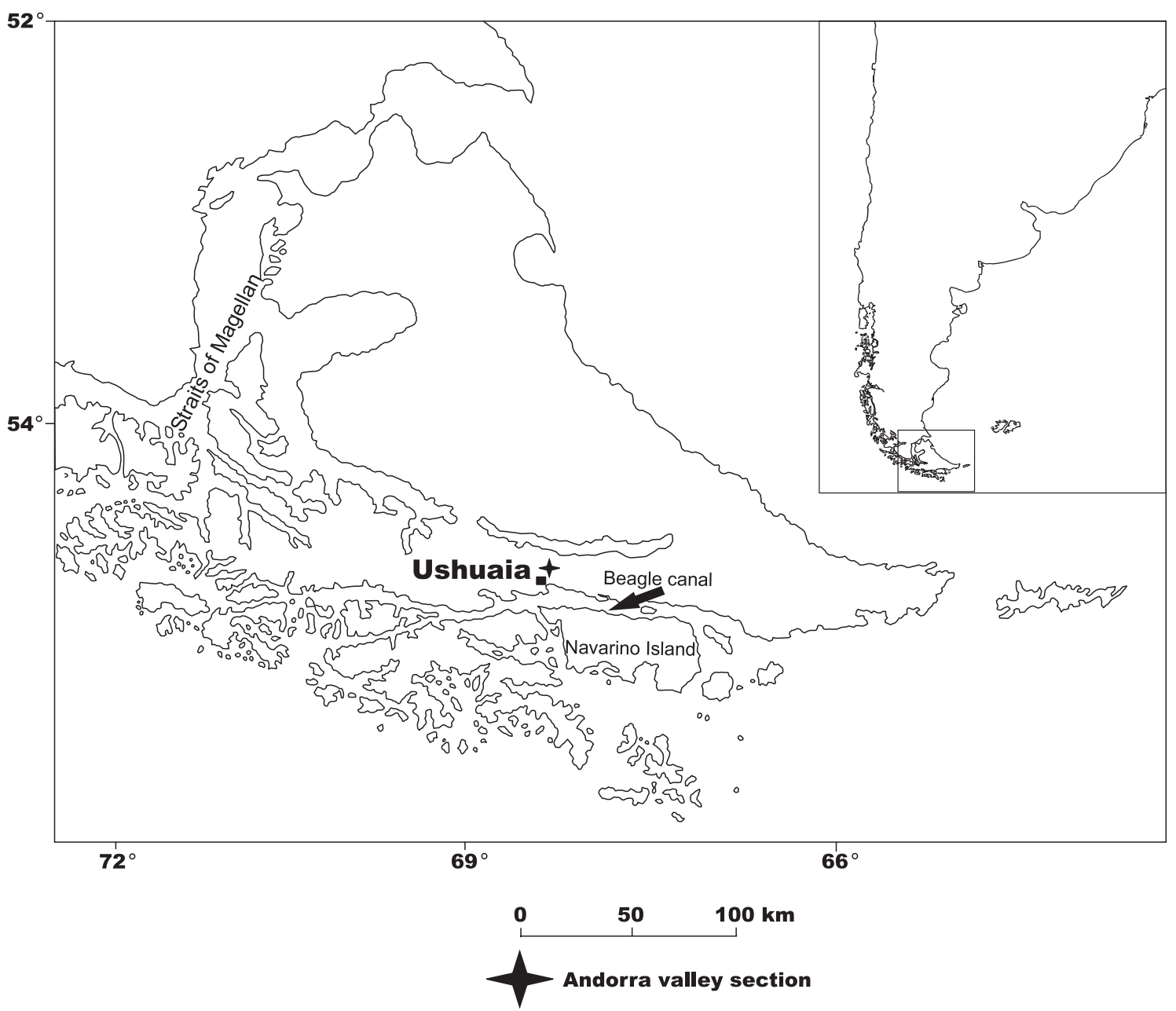

Fig. 1. Map of Tierra del Fuego, showing study site location at Ushuaia. Box in index map shows area of enlargement.

local vegetation cover is primarily composed of Marsippospermum grandiflorum, Carex curta, and Sphagnum magellanicum, which grows from the highest hummock microforms (depth to local water tables of $>60 \mathrm{~cm}$ ) down to pool margins. Pool microforms are infrequent, but possess Sphagnum sect. Cuspidata and Tetroncium magellanicum which grows at the pool margins. Empetrum rubrum and Nothofagus antarctica appear to be restricted to microforms where local water tables are lower. Forests of Nothofagus pumilio surround the bogs in the Valle de Andorra. The mean annual temperature and precipitation is estimated at $6{ }^{\circ} \mathrm{C}$ and 450-600 mm, respectively, and annual cloudiness surpasses $60 \%$ (values taken from Roig et al., 1996).

Macrofossil samples were collected at contiguous $1-\mathrm{cm}$ sample intervals from the 1-m-long Valle de Andorra (AND1) peat core. These were boiled with $5 \% \mathrm{KOH}$ and sieved (mesh diameter $100 \mu \mathrm{m})$. Macrofossils were identified using a binocular microscope (x10-50). Abundances of each peat component were expressed as percentage volume of the subsample (ca. $5 \mathrm{~cm}^{3}$ ). Microfossil samples of ca. 1 $\mathrm{cm}^{3}$ volume (precise volume estimated by immersion) were treated with KOH and acetolyzed (Fægri and Iversen, 1989).
To estimate microfossil concentrations Lycopodium spores were added to the sample (Stockmarr, 1971). Pollen and fungal microfossils were counted at $2-\mathrm{cm}$ sample intervals (pollen sum of 200 to 500 grains per sample). Fungal microfossils are presented as percentages of 100 pollen grains (aquatics and cryptogams excluded).

Pollen identifications were made using modern reference material in the Universidad Nacional del Sur Palynology Laboratory and published descriptions and keys (Heusser, 1971; Markgraf and D'Antoni, 1978). The degree of peat humification of 100 contiguous samples was assessed using a modified version of the Bahnson colorimetric method (Blackford and Chambers, 1993). Testate amebae from a further 100 contiguous samples were analyzed following Hendon and Charman (1997). Counting was done until 150 testate amebae were recorded.

Thirteen samples of Sphagnum leaves and/or stems were radiocarbon dated using AMS (Kilian et al., 1995, 2000; Table 1). Only Sphagnum subfossils (leaves and stems) were selected from the macrofossil samples. Samples were cleaned to remove roots of Ericaceae and Cyperaceae and fungal mycelium, transferred to a petri dish containing 
Table 1

Radiocarbon and calibration/wiggle-match date results for AND1

\begin{tabular}{|c|c|c|c|c|c|c|c|c|c|}
\hline $\begin{array}{l}\text { Date } \\
\text { (No.) }\end{array}$ & $\begin{array}{l}\text { Ua } \\
\text { number }\end{array}$ & $\begin{array}{l}\delta^{13} \mathrm{C} \\
(\%) b\end{array}$ & $\begin{array}{l}{ }^{14} \mathrm{C} \text { age } \\
\left({ }^{14} \mathrm{C} \text { yr B.P. }\right)\end{array}$ & $\begin{array}{l}{ }^{14} \mathrm{C} \text { age }\left({ }^{14} \mathrm{C} \text { yr B.P.) }\right. \\
\text { with } 30 \text {-year } \\
\text { Southern } \\
\text { Hemisphere offset } \\
\text { (Mook, 1986) }\end{array}$ & $\begin{array}{l}\text { Laboratory } \\
\text { standard } \\
\text { deviation } \\
\text { (B.P.) }\end{array}$ & $\begin{array}{l}\text { Midpoint } \\
\text { sample } \\
\text { depth } \\
(\mathrm{cm})\end{array}$ & $\begin{array}{l}\text { CALIB } 4.3 \\
\text { calibration ( } 2 \sigma \\
\text { range and midpoint } \\
\text { rounded to the } \\
\text { nearest decade) }\end{array}$ & $\begin{array}{l}\text { Wiggle-match date- } \\
\text { best match using } \\
\text { maximum likelihood } \\
\text { rounded to the } \\
\text { nearest decade }\end{array}$ & $\begin{array}{l}\text { Weighted least } \\
\text { squares confidence } \\
\text { intervals for wiggle- } \\
\text { match date (min, } \\
\text { max, } 2 \text { SD range }\end{array}$ \\
\hline 1 & 19905 & -27.7 & 200 & 170 & 45 & 31.5 & $\begin{array}{l}\text { cal A.D. } 1655-1950 \text {; } \\
\text { cal A.D. } 1800\end{array}$ & $\mathrm{X}$ & $\mathrm{X}$ \\
\hline 2 & 18763 & -29.5 & 355 & 325 & 60 & 49.5 & $\begin{array}{l}\text { cal A.D. } 1444-1662 \text {; } \\
\text { cal A.D. } 1550\end{array}$ & $\mathrm{X}$ & $\mathrm{X}$ \\
\hline 3 & 19906 & -25.4 & 1005 & 975 & 45 & 67.5 & $\mathrm{X}$ & cal A.D. 1100 & cal A.D. $1090-1156$ \\
\hline 4 & 19907 & -26.6 & 865 & 835 & 45 & 69.5 & $\mathrm{X}$ & cal A.D. 1080 & cal A.D. $1073-1123$ \\
\hline 5 & 19908 & -26.2 & 840 & 810 & 45 & 71.5 & $\mathrm{X}$ & cal A.D. 1060 & cal A.D. $1055-1090$ \\
\hline 6 & 19909 & -25.5 & 995 & 965 & 40 & 73.5 & $\mathrm{X}$ & cal A.D. 1040 & cal A.D. $1038-1057$ \\
\hline 7 & 19910 & -25.4 & 1010 & 980 & 40 & 75.5 & $\mathrm{X}$ & cal A.D. 1020 & cal A.D. $1018-1028$ \\
\hline 8 & 19911 & -25.6 & 1040 & 1010 & 40 & 77.5 & $\mathrm{X}$ & cal A.D. 1010 & cal A.D. 984-1008 \\
\hline 9 & 19912 & -26.3 & 1115 & 1085 & 40 & 79.5 & $\mathrm{X}$ & cal A.D. 990 & cal A.D. 951-990 \\
\hline 10 & 19913 & -25.9 & 1135 & 1105 & 40 & 81.5 & $\mathrm{X}$ & cal A.D. 970 & cal A.D. 918-972 \\
\hline 11 & 19914 & -24.7 & 1205 & 1175 & 40 & 83.5 & $\mathrm{X}$ & cal A.D. 950 & cal A.D. $884-955$ \\
\hline 12 & 19915 & -25.8 & 1250 & 1220 & 40 & 85.5 & $\mathrm{X}$ & cal A.D. 930 & cal A.D. $851-937$ \\
\hline 13 & 18764 & -27.5 & 1415 & 1385 & 65 & 99.5 & $\begin{array}{l}\text { cal A.D. } 540-776 \\
\text { cal A.D. } 660\end{array}$ & $\mathrm{X}$ & $\mathrm{X}$ \\
\hline
\end{tabular}

deionized water and then pretreated for radiocarbon analysis (Speranza et al., 2000). A ${ }^{14} \mathrm{C}$ offset was applied to these Southern Hemisphere samples although the exact value is the

Table 2

Macrofossil and fungal microfossil zonation for AND1

Zone AND1-a (100-85 cm). Peat matrices are largely composed of Sphagnum magellanicum (72-93\%), with relatively low amounts of Empetrum/Ericaceae roots (2-15\%). Type 126 Hyphopodia of Gaeumannomyces sp. confirm the presence of Carex sp. (Pals et al., 1980).

Zone AND1-b (84-81 cm). A decrease in S. magellanicum (67-58\%) was recorded in addition to an increase in Empetrum/Ericaceae roots (25-30\% of the peat matrices), indicating a reduction of local water table depths. Abundances of Type 811 spores increase.

Zone AND1-c (80-48 cm). Percentages of S. magellanicum and detached Sphagnum stems increase (maximum values of 93 and $15 \%$ were recorded, respectively). Between 80 and $68 \mathrm{~cm}$ fungal Types 810 and 811 are almost absent. Elevated values of Type 810 ascospores occur between 57 and $53 \mathrm{~cm}$. Increased charcoal occurs from 53 to $49 \mathrm{~cm}$, indicating the occurrence of local fires.

Zone AND1-d $(47-27 \mathrm{~cm})$. Fluctuations in local water table depths may have occurred, since there are clear oscillations in the percentages of identifiable Sphagnum and Empetrum/Ericaceae roots. Sequential increases in Types 812, 811, and 810 fungal microfossils occur.

Zone AND1-e $(26-14 \mathrm{~cm})$. Increases in S. magellanicum and a reduction in Empetrum/Ericaceae roots suggest that an increase in mire surface wetness occurred. Type 810 ascospores decline.

Zone AND1-f (13-9 cm). The lowest values of $S$. magellanicum and high values of Empetrum/Ericaceae roots and unidentifiable organic material (40 and $25 \%$ ) indicate a marked decrease in mire surface wetness. The highest values of Type 5 conidia were recorded here, supporting the occurrence of dry conditions (van Geel, 1978).

Zone AND1-g $(8-0 \mathrm{~cm})$. Mire surface wetness appears to have increased as high values of $S$. magellanicum recur. Fungal microfossils are very infrequent.

Zonation-optimal splitting by information content, PSIMPOLL 4.10. Features of zones. subject of continuing research (see Stuiver et al., 1998, for details). We subtracted 30 years from all radiocarbon measurements following the recommendations of Mook (1986).

The ${ }^{14} \mathrm{C}$ ages of the samples from 68 to $86 \mathrm{~cm}$ (dates $3-$ 12, Fig. 2) have been converted to calendar ages using ${ }^{14} \mathrm{C}$ wiggle-match dating (van Geel and Mook, 1989), assuming a constant peat accumulation rate. The best fit (using maximum likelihood) and confidence intervals (using weighted least squares) were calculated for each date after the technique of Blaauw et al. (2003; Fig. 2). The basal date at $100 \mathrm{~cm}$ and upper samples at 50 and $32 \mathrm{~cm}$ were calibrated using CALIB 4.3, since an insufficient density of ${ }^{14} \mathrm{C}$ dates was available to wiggle-match these sections of the peat stratigraphy. Zonation of the record of local vegetation in the macrofossil diagram (Fig. 3 and Table 2) was performed using optimal splitting by information content (Bennett, 1996; Birks and Gordon, 1985) within Psimpoll version 4.10. Seeds of E. rubrum and the macroscopic charcoal fragments were excluded from this zonation procedure, because they were not counted as percentages. The fungal microfossils were also excluded from the zonation because their counts are an order of magnitude larger than the plant macrofossils and would therefore heavily bias the zonation of the local vegetation development. Relationships between the plant macrofossil components and the fungal microfossils were explored using principal components analysis (PCA) (Fig. 4).

\section{Results}

The AND1 macrofossil stratigraphy registers low local water tables in zones AND1-b, AND1-d, and AND1-f (Fig. 3), because percentage abundances of Empetrum/Ericaceae 


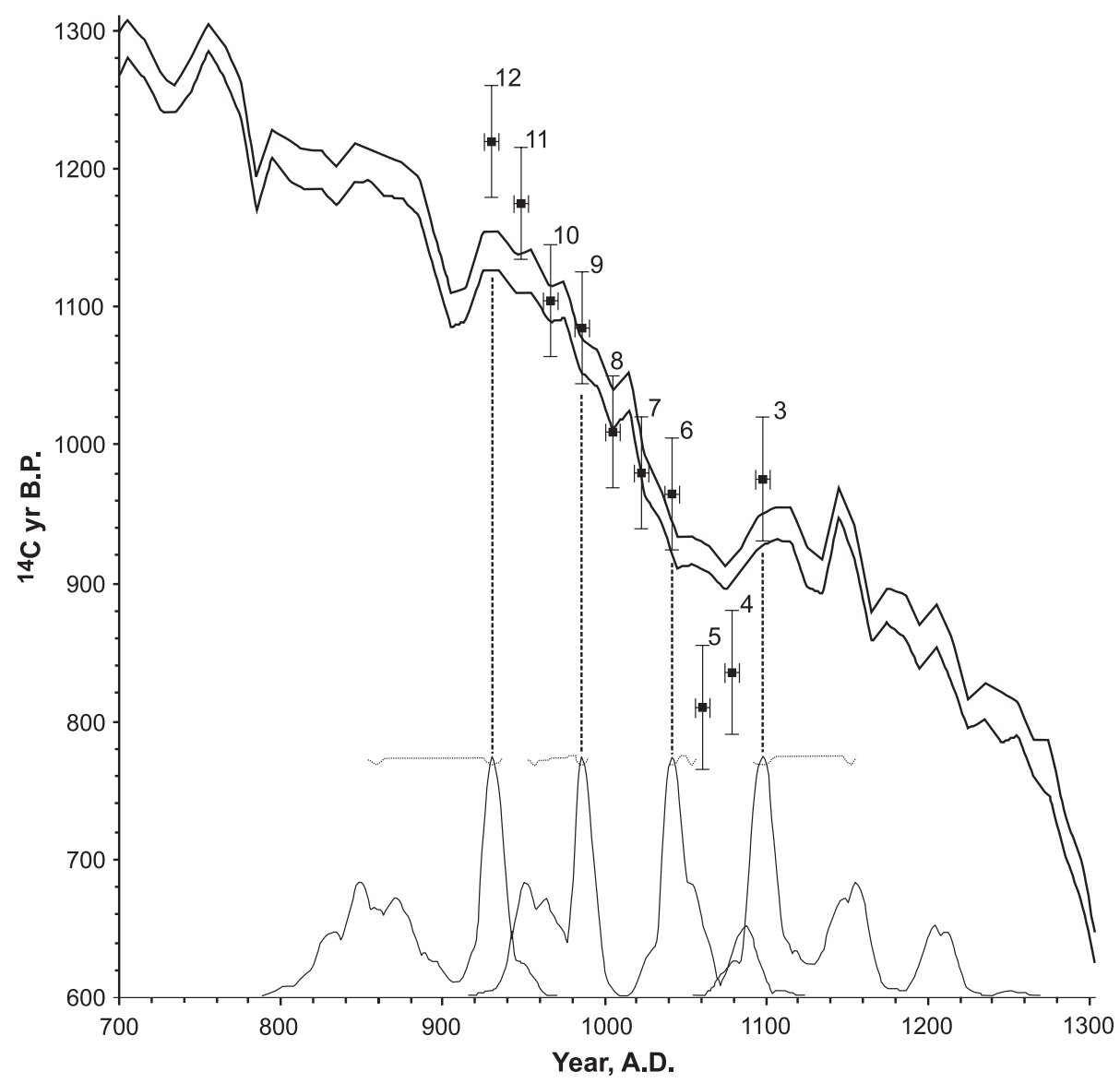

Fig. 2. Numerical wiggle-match fit of ${ }^{14} \mathrm{C}$ AMS dates 3-12. Thick lines show 1 standard deviation ( $\left.\sigma\right)$ error envelope of INTCAL98 calibration curve (Stuiver et al., 1998). Vertical bars of ${ }^{14} \mathrm{C}$ samples show 1- $\sigma$ error bars; horizontal bars show deposition period of the samples. Projected on the calendar year axis are the WLS (weighted least squares, concave shapes) and MLH (maximum likelihood, convex shapes) probability distributions of selected dated levels. The vertical scale is arbitrary. Maximum values of WLS indicate 2- $\sigma$ limits. The dated levels are placed on the calendar axis as proposed by the optimal MLH solution (after Blaauw et al., 2003).

roots are relatively high. The PCA ordination (Fig. 4) shows that the fungal microfossils (Types $5,126,810,811,813$, and 814; see Fig. 5) occur with the plant macrofossils, indicative of dry conditions (Empetrum/Ericaceae roots and wood and unidentifiable organic material), since the angles between these vectors are relatively low. A clear separation between these components and S. magellanicum suggests the primary direction of variance of PCA axis 1 represents a wetness gradient of the mire surface (increasing numbers on the $x$ axis indicate decreasing mire surface wetness). Furthermore, high PCA axis 1 values of the samples are associated with low transmission values (indicating high peat decomposition), high pollen concentrations of Empetrum/Ericaceae (Empetrum is a species which indicates low mire surface wetness; Heusser, 1989), and relatively high percentages of Assulina muscorum and Corythion dubium (Fig. 6, zonation details Table 3). The 15 surface samples confirm the relationship between relatively low, local, water tables and increased abundance of A. muscorum (Fig. 7). Three periods of high surface wetness occurred between ca.
A.D. 890-950 (AND1-II), A.D. 1030-1100 (AND1-IV), and A.D. 1800-1930 (AND1-VI). Zones AND1-I, AND1III, and AND1-VII (ca. A.D. 660-870, 960-1020, and $1940-1950$, respectively) seemingly represent warmer and/ or drier conditions.

\section{Discussion}

The paleoclimatic interpretations offered here should be applied cautiously, as only a single borehole was examined. Multiple cores from raised peat bogs have shown that it is not always possible to replicate changes in mire surface wetness (Mauquoy et al., 2002), and the possibility exists that the data register only local successional changes. The latter appears unlikely because changes in the peat stratigraphy could be followed over tens of meters in the 1-m-deep drainage ditches from which the samples were obtained. With the exception of the section dated by ${ }^{14} \mathrm{C}$ wigglematching, the dating control is relatively poor, and so the 


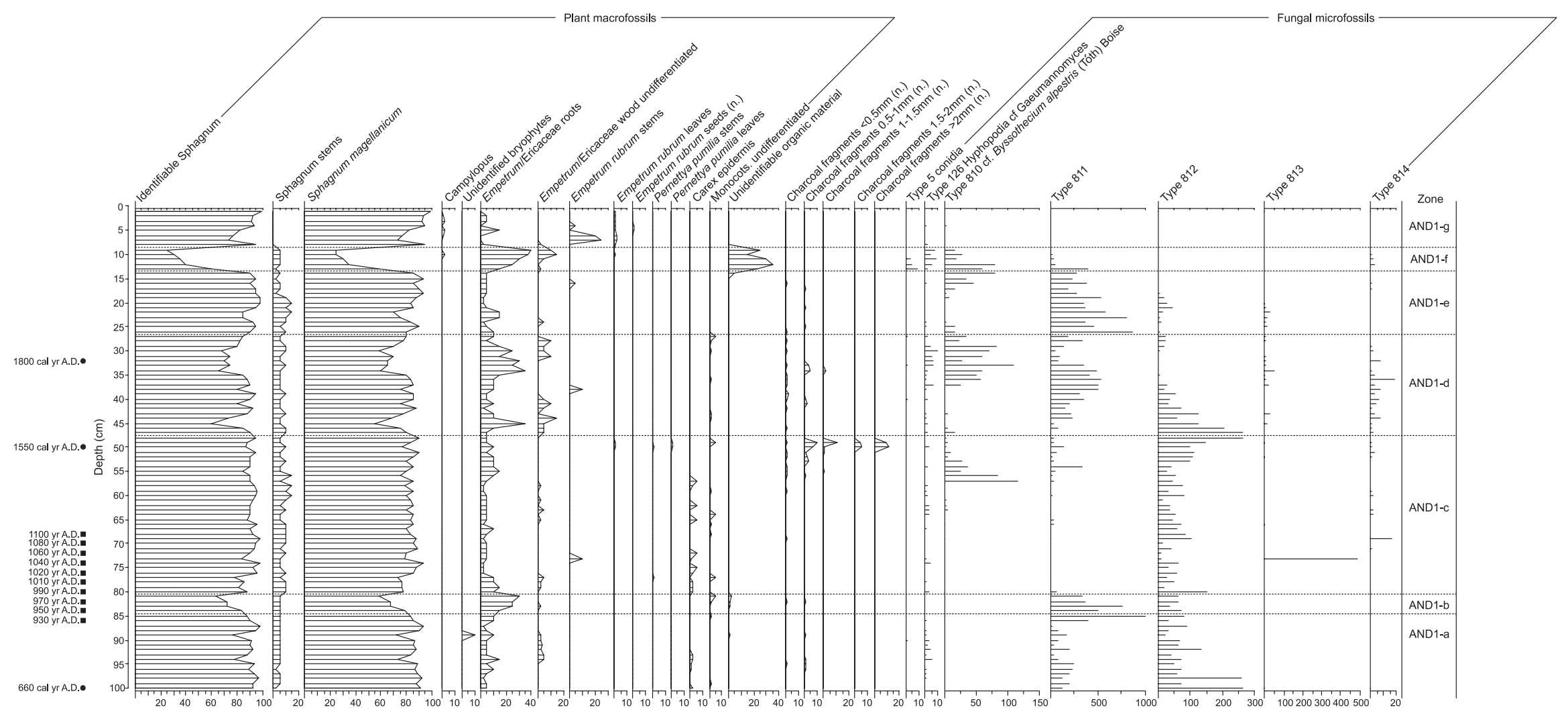

Fig. 3. AND1 macrofossils and macroscopic charcoal particles. Volume abundances of all components are expressed as percentages with the exception of E. rubrum seeds and charcoal fragments, which are presented as the number (n) found in each ca. $5-\mathrm{cm}^{3}$ subsample. Fungal microfossils are presented as percentages related to 100 pollen grains (aquatics and cryptogams excluded). 
Table 3

AND1 composite diagram zonation

\begin{tabular}{|c|c|}
\hline Zonation-“eye" only & Reconstructed mire surface \\
\hline Features of zones & Wetness with date ranges \\
\hline $\begin{array}{l}\text { Zone AND1-I }(99-89 \mathrm{~cm}) \text {. In this zone } \\
\text { the highest concentration values of } \\
\text { Empetrum/Ericaceae were recorded. } \\
\text { Peat transmission is relatively low. }\end{array}$ & $\begin{array}{l}\text { Low mire surface wetness } \\
\text { ca. A.D. } 660-870^{\mathrm{a}}\end{array}$ \\
\hline $\begin{array}{l}\text { Zone AND1-II }(88-84 \mathrm{~cm}) \text {. Empetrum/ } \\
\text { Ericaceae pollen concentrations decrease } \\
\text { and lower PCA axis } 1 \text { values were } \\
\text { recorded. }\end{array}$ & $\begin{array}{l}\text { High mire surface wetness } \\
\text { ca. A.D. } 890-950\end{array}$ \\
\hline $\begin{array}{l}\text { Zone AND1-III }(83-76 \mathrm{~cm}) \text {. A new } \\
\text { resurgence of Empetrum/Ericaceae is } \\
\text { recorded, followed by increases in } \\
\text { Assulina muscorum. }\end{array}$ & $\begin{array}{l}\text { Low mire surface wetness } \\
\text { ca. A.D. } 960-1020\end{array}$ \\
\hline $\begin{array}{l}\text { Zone AND1-IV }(75-68 \mathrm{~cm}) \text {. Peat } \\
\text { transmission increases, } \text { A. muscorum } \\
\text { abundances decrease, and low values of } \\
\text { PCA axis } 1 \text { scores are recorded. }\end{array}$ & $\begin{array}{l}\text { High mire surface wetness } \\
\text { ca. A.D. } 1030-1100\end{array}$ \\
\hline $\begin{array}{l}\text { Zone AND1-V }(67-33 \mathrm{~cm}) \text {. Fluctuations in } \\
\text { transmission, Empetrum/Ericaceae pollen } \\
\text { concentrations and PCA axis } 1 \text { scores } \\
\text { occur. }\end{array}$ & $\begin{array}{l}\text { Oscillations in mire } \\
\text { surface wetness } \\
\text { ca. A.D. } 1130-1790^{\text {a }}\end{array}$ \\
\hline $\begin{array}{l}\text { Zone AND1-VI }(32-12 \mathrm{~cm}) \text {. Low } \\
\text { concentrations of Empetrum/Ericaceae } \\
\text { occur and PCA axis } 1 \text { scores decrease. }\end{array}$ & $\begin{array}{l}\text { High mire surface wetness } \\
\text { ca. A.D. } 1800-1930^{\mathrm{a}}\end{array}$ \\
\hline $\begin{array}{l}\text { Zone AND1-VII }(11-8 \mathrm{~cm}) \text {. Low } \\
\text { peat transmission, high values of } \\
\text { A. muscorum and Corythion dubium, } \\
\text { high values of Empetrum/Ericaceae } \\
\text { and high PCA axis } 1 \text { scores all occur. }\end{array}$ & $\begin{array}{l}\text { Low mire surface wetness } \\
\text { ca. A.D. } 1940-1950^{\mathrm{a}}\end{array}$ \\
\hline $\begin{array}{l}\text { Zone AND1-VIII }(7-0 \mathrm{~cm}) \text {. Increases in } \\
\text { peat transmission, decreases in } \\
\text { concentration values of Empetrum/ } \\
\text { Ericaceae and PCA axis } 1 \text { scores occur. }\end{array}$ & $\begin{array}{l}\text { High mire surface wetness } \\
\text { ca. A.D. } 1960-\text { present }^{\mathrm{a}}\end{array}$ \\
\hline
\end{tabular}

${ }^{a}$ Ages linearly interpolated between the ${ }^{14} \mathrm{C}$ AMS dates that were calibrated (midpoint of the 2- $\sigma$ calibration range).

age ranges for zones AND1-I, AND1-II, and AND1-V to AND1-VIII inclusive (Fig. 6) can provide only an approximate age for the reconstructed changes in mire surface wetness. We therefore focus attention on the inferred paleoclimatic changes registered in zones AND1-III and AND1IV, for which have greater confidence in the chronology.

\section{Evidence for the Medieval Warm Period}

The evidence for drier conditions in zone AND1-III (ca. cal A.D. 960-1020) indicating warming seems to correspond to the Medieval Warm Period (MWP, as defined in the Northern Hemisphere). This interval compares well to the date range of A.D. 950-1045 based on Northern Hemisphere extratropical tree-ring data (Esper et al., 2002). These dendrochronological data also suggest the MWP may have begun in the early A.D. 900s. The extent, timing, and nature of the Medieval Warm period are uncertain. According to Broecker (2001), evidence for a global Medieval Warm Period is circumstantial and because of the relative scarcity of Southern Hemisphere paleoclimatic data, Crowley and Lowery (2000) suggest the term Medieval Warm Period should be restricted to the Northern Hemisphere only. Our reconstruction for warm/dry conditions between ca. A.D. 960-1020 closely agrees with Northern Hemisphere tree-ring evidence for the MWP and shows that the MWP was possibly synchronous in both hemispheres, as suggested by Villalba (1994).

\section{Evidence for Little Ice Age climatic deteriorations}

Zone AND1-IV suggests cooler and/or wetter conditions between ca. A.D. 1030-1100, which may represent a Southern Hemisphere precursor to the Little Ice Age (LIA). Regional evidence for climatic deteriorations is suggested by advances of a lobe of the Bahia Pia glacier system in the Cordillera Darwin, Tierra del Fuego (Kuylenstierna et al., 1996), reaching one of its maximum positions between 940 and 675 B.P. (cal A.D. $980-1260$ and cal A.D. $1220-1420$ at $2 \sigma$, respectively). Our highprecision ${ }^{14} \mathrm{C}$ chronology possibly refines this agerange for the start of cooling in Tierra del Fuego. A temperature profile from Law Dome core (Dahl-Jensen et al., 1999) has minima at A.D. 1250 and $1790-1850$, and the magnetic susceptibility record of the Antarctic Palmer Deep marine core (Domack et al., 2001) also indicates a possible LIA signal at ca. 700 B.P. (cal A.D. 1250). Our age range for the first cooling episode predates this (ca. cal A.D. 1030$1100)$, even with the maximum weighted least squares estimate for date 3 (A.D. 1156, Table 1). We do not have sufficiently good dating control in zone AND1-VI, but there is a possibility that the evidence for cooler and/or wetter conditions at ca. A.D. 1800-1930 (low concentrations of Empetrum/Ericaceae and low PCA axis 1 scores) may correspond to a period of low temperatures (A.D. 1790-1850) identified by Dahl-Jensen et al. (1999) and to tree-ring evidence for cool summer temperatures in Tierra del Fuego at ca. A.D. 1850 and A.D. 1880 (Boninsegna et al., 1989).

The AND1 peat stratigraphy displays increased mire surface wetness between ca. A.D. 1030-1100 and ca. cal A.D. 1800-1930. However, the chronology for this period of cooler and/or wetter conditions is poor. Dating control for the peat stratigraphy postdating zone AND1-IV is also poor, but fluctuations in mire surface wetness registered in zone AND1-V may correspond to another cooler/wetter period identified in the wider study region. For example, summer temperature reconstructions from tree-rings in northern Patagonia (ca. $1500 \mathrm{~km}$ to the north northwest of the Valle de Andorra) suggest a warm period occurred from A.D. 1080-1250, followed by a prolonged cold period from A.D. 1270 to A.D. 1660, possibly peaking around A.D. 1340 and 1640 (Villalba, 1990, 1994). This period does not appear to have been uniformly cold, since the tree-ring data suggest warming occurred between A.D. 


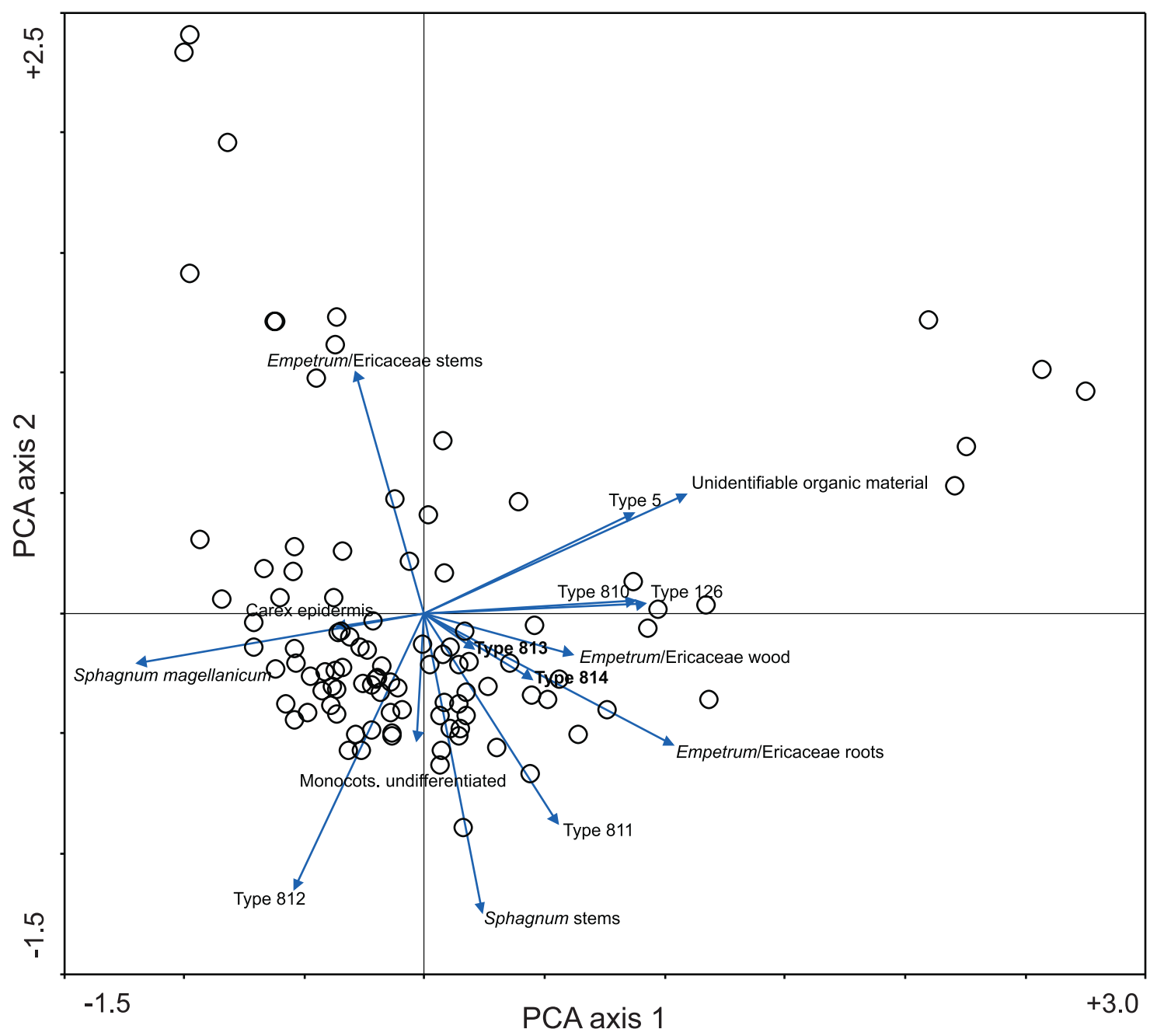

Fig. 4. Principal components analysis biplot of the AND1 plant macrofossil and fungal microfossil data. The ordination was performed using CANOCO for Windows version 4.02, using the following options: focus scaling on interspecies correlations, species scores divided by standard deviation, species data log transformed, species centered and standardized. Campylopus, E. rubrum leaves, Pernettya pumilia stems and leaves were excluded.

1380 and 1520 . Finally, warmer conditions were reconstructed between A.D. 1720 and 1790 (Villalba, 1990). An advance of the Soler Glacier in the North Patagonian Icefield has been dated using in situ tree remains to ca. A.D. 1222-1342 (Glasser et al., 2002), which supports the climatic reconstructions of Villalba. More records with greater numbers of ${ }^{14} \mathrm{C}$ dates could serve to resolve the chronology of the evidence for climate change in Tierra del Fuego and establish if the LIA climatic deteriorations detected in the wider study region and the Northern Hemisphere (Luckman and Villalba, 2001) also occurred here.

\section{Acknowledgments}

This research was supported through a European Community Marie Curie Fellowship (Contract HPMF-CT-
2000-01056). We thank Dr. Andrea Coronato, Laboratorio Geología del Cuaternario CADIC-CONICET, Ushuaia, Argentina, for logistical support. We also thank Professor Keith Bennett, Palaeobiology Program, Department of Earth Sciences, Uppsala University, for advice and many discussions of dating, statistics, and the optimal use of psimpoll 4.10. Dr. André Aptroot, Utrecht, The Netherlands, kindly confirmed the identification of Byssothecium alpestris (Tóth) Boise.

\section{Appendix A. Descriptions of newly distinguished types in core AND1}

\section{A.1. Type 810 (Figs. 5: 2, 3a, 3b)}

Ascospores (44-) 49-59 × 16-20 $\mu \mathrm{m}$, three septate, inequilateral (one side almost straight or even concave), 


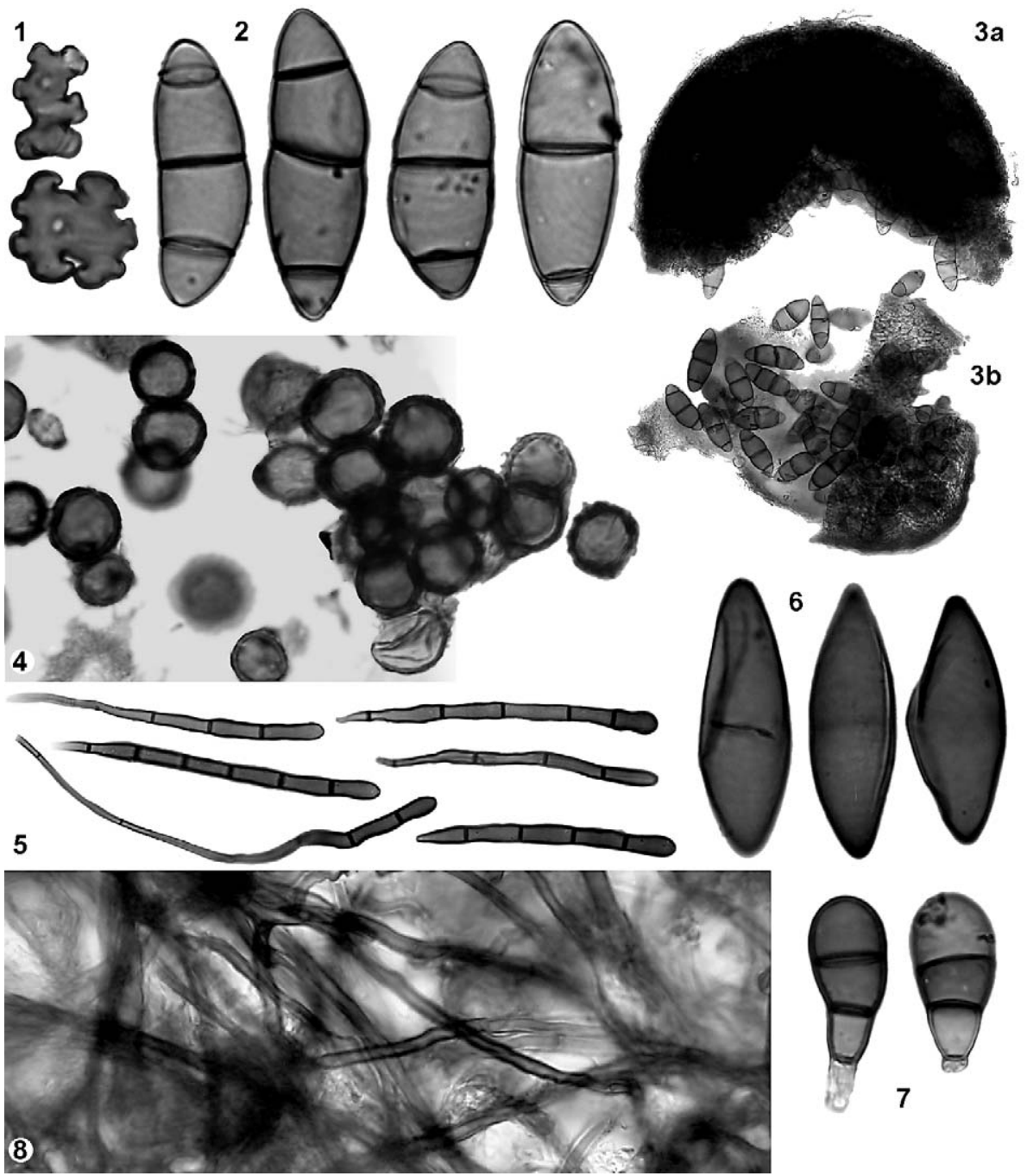

Fig. 5. AND1 fungal microfossils. (1) Hyphopodia of the fungus Gaeumannomyces cf. caricis (Type 126; original magnification $\times 640$ ); (2) Type 810 cf. Byssothecium alpestris (Tóth) Boise, ascospores (Boise, 1989; $\times 640)$; (3a,b) Broken fruit bodies of the Type 810 fungus, showing ascospores $(\times 160)$; $(4)$ Type 811 spores $(\times 640)$; (5) Type 812 conidia or chlamydospores $(\times 320)$; (6) Type 813 ascospores $(\times 640)$; (7) Type 814 conidia or chlamydospores $(\times 640)$; (8) mycelium $(\times 640)$.

slightly constricted at the septa. Each septum showing a ca. 0.5 - $\mu \mathrm{m}$-wide pore. Two-septate and four-septate spores also occur, but these are rare.

Fruit bodies globose, $150-200 \mu \mathrm{m}$ in diameter (only broken fruit bodies were observed in pollen slides).

\section{A.2. Type 811 (Fig. 5: 4)}

Spores globose, 10-18 (-23) $\mu \mathrm{m}$ in diameter, with roughly textured walls. Often groups of clustered spores were found in the microfossil slides. The origin of Type 811 is unknown (fungus?), but it closely resembles Type 38 (van Geel, 1972), which occurs in NW European raised bog deposits. However, no conclusions could be drawn from the record of Type 38 in those deposits (van Geel, 1978).

\section{A.3. Type 812 (Fig. 5: 5)}

Fungal conidia or chlamydospores transversely (3-) 6$10(-16)$ septate, $(50-) 120-200(-250) \mu \mathrm{m}$ long and 5$8 \mu \mathrm{m}$ wide, formed at the ends of septate ca $2.5-\mu \mathrm{m}$-wide hyphae.

\section{A.4. Type 813 (Fig. 5: 6)}

Ascospores one septate, $46-52 \times 17-20 \mu \mathrm{m}$. Septum often no longer attached to the spore wall. Nonseptate spores were also observed.

\section{A.5. Type 814 (Fig. 5: 7)}

Fungal conidia or chlamydospores transversely three septate, (25-) 31-38 $\mu \mathrm{m}$ long and 13-17 $\mu \mathrm{m}$ wide. 


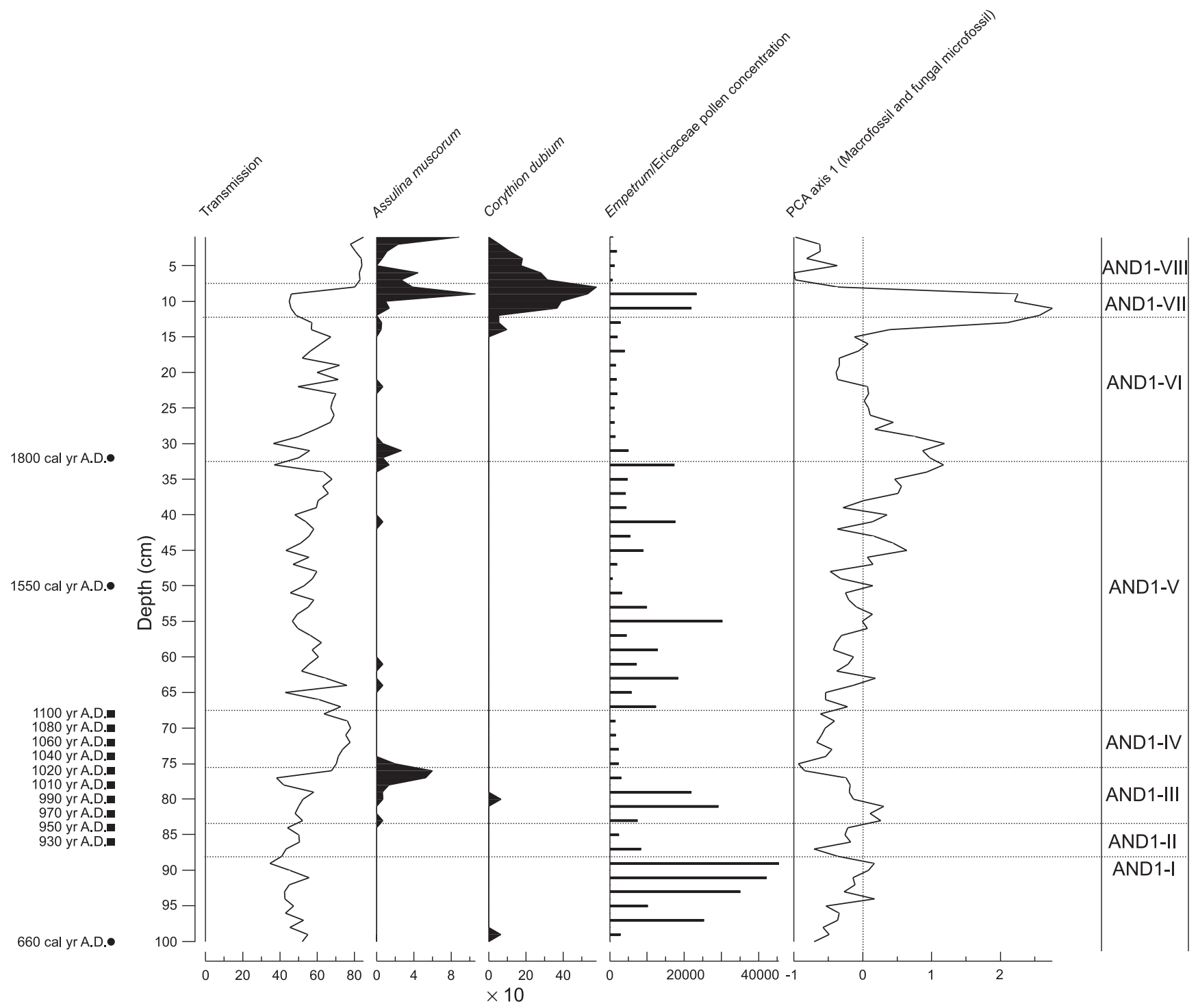

Fig. 6. AND1 composite diagram. Pollen concentrations of Empetrum/Ericaceae expressed as grains $\mathrm{cm}^{-3}$, Transmission, A. muscorum and Co. dubium are percentages. PCA axis 1 sample scores from Fig. 4 plotted versus age/depth.

Assulina muscorum \% abundance

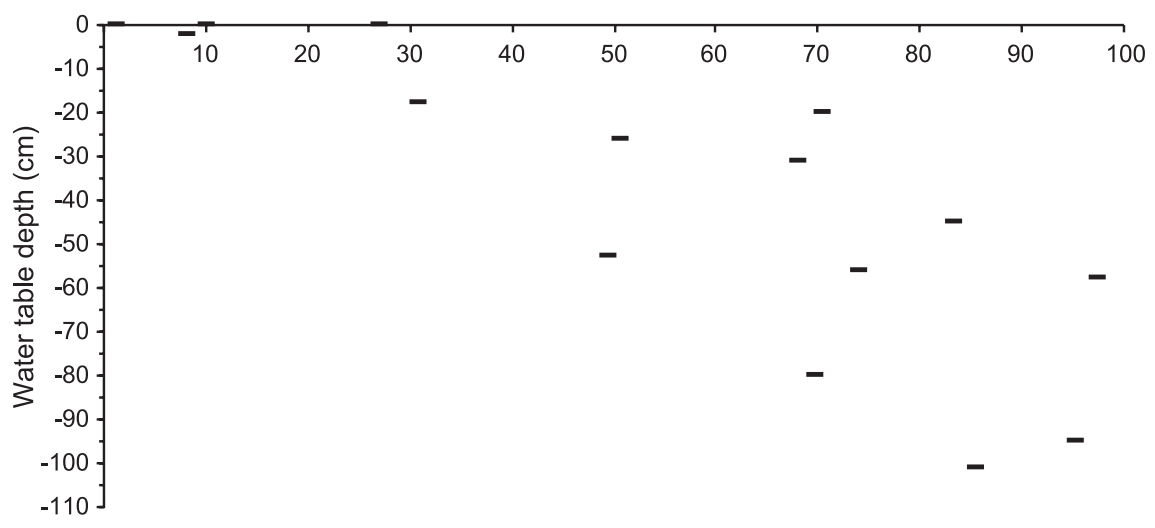

Fig. 7. Depth of water table plotted against the percentage (testate amebae sum of 150) of A. muscorum (black rectangles) from 15 sites on the intact peat bog surface (S $\left.54^{\circ} 45^{\prime}, \mathrm{W} 68^{\circ} 19\right)$. Surface samples contained S. magellanicum only. 


\section{References}

Ashworth, A.C., Markgraf, V., Villagran, C., 1991. Late Quaternary climatic history of the Chilean Channels based on fossil pollen and beetle analyses, with an analysis of the modern vegetation and pollen rain. Journal of Quaternary Science 6, 279-291.

Barber, K.E., Chambers, F.M., Maddy, D., Stoneman, R., Brew, J.S., 1994. A sensitive high-resolution record of late Holocene climatic change from a raised bog in northern England. The Holocene 4, $198-205$.

Bennett, K.D., 1996. Determination of the number of zones in a biostratigraphical sequence. New Phytologist 132, 155-170.

Birks, H.J.B., Gordon, A.D., 1985. Numerical Methods in Quaternary Pollen Analysis. Academic Press, London.

Blackford, J.J., Chambers, F.M., 1993. Determining the degree of peat decomposition for peat based palaeoclimatic studies. International Peat Journal 5, 7-24.

Blaauw, M., van Geel, B., Heuvelink, G.B.M., Mauquoy, D., van der Plicht, J., 2003. A numerical approach to ${ }^{14} \mathrm{C}$ wiggle-match dating of organic deposits: best fits and confidence intervals. Quaternary Science Reviews 22, 1485-1500.

Boise, J.R., 1989. On Hadrospora, a new genus in the Phaeosphaeriaceae, and Byssothecium alpestris in the Dacampiaceae. Memoirs of the New York Botanical Garden 49, 308-310.

Boninsegna, J.A., Keegan, J., Jacoby, G.C., D’Arrigo, R.D., Holmes, R.L., 1989. Dendrochronological studies in Tierra del Fuego, Argentina. Quaternary of South America and Antarctic Peninsula 7, 305-326.

Borromei, A.M., 1995. Análisis polínico de una turbera holocénica en el Valle de Andorra, Tierra del Fuego, Argentina. Revista Chilena de Historia Natural 68, 311-319.

Broecker, W.S., 2001. Was the Medieval Warm Period global? Science 291, $1497-1499$.

Charman, D.J., Hendon, D., Packman, S., 1999. Multiproxy surface wetness records from replicate cores on an ombrotrophic mire: implications for Holocene palaeoclimate records. The Holocene 14, $451-463$.

Crowley, C.J., Lowery, T.S., 2000. How warm was the Medieval Warm Period? Ambio 29, 51-54.

Dahl-Jensen, D., Morgan, V.I., Elcheikh, A., 1999. Monte Carlo inverse modelling of the Law Dome (Antarctica) temperature profile. Annals of Glaciology 29, 145-150.

Domack, E., Leventer, A., Dunbar, R., Taylor, F., Brachfeld, S., Sjunneskog, C., ODP Leg 178 Scientific Party, 2001. Chronology of the Palmer Deep site, Antarctic Peninsula: a Holocene palaeoenvironmental reference for the circum-Antarctic. The Holocene 11, $1-9$.

Esper, J., Cook, E.R., Schweingruber, F.H., 2002. Low-frequency signals in long tree-ring chronologies for reconstructing past temperature variability. Science $295,2250-2253$.

Fægri, K., Iversen, J., 1989. Textbook of Pollen Analysis. Wiley, Chichester

Glasser, N.F., Hambrey, M.J., Aniya, M., 2002. An advance of Soler Glacier, North Patagonian Icefield, at c. AD 1222-1342. The Holocene 12, $113-120$.

Hendon, D., Charman, D.J., 1997. The preparation of testate amoebae (Protozoa: Rhizopoda) samples from peat. The Holocene 7, 199-205.

Heusser, C.J., 1971. Pollen and Spores of Chile. Univ. of Arizona Press, Tucson.

Heusser, C.J., 1989. Late Quaternary vegetation and climate of Southern Tierra del Fuego. Quaternary Research 31, 396-406.

Heusser, C.J., 1995. Three Late Quaternary pollen diagrams from Southern Patagonia and their palaeoecological implications. Palaeogeography, Palaeoclimatology, Palaeoecology 118, 1-24.

Heusser, C.J., 1998. Deglacial paleoclimate of the American sector of the Southern Ocean: Late Glacial-Holocene records from the latitude of Canal Beagle (55 degrees S), Argentine Tierra del Fuego. Palaeogeography, Palaeoclimatology, Palaeoecology 141, 277-301.
Kilian, M.R., van der Plicht, J., van Geel, B., 1995. Dating raised bogs: new aspects of AMS ${ }^{14} \mathrm{C}$ wiggle matching, a reservoir effect and climatic change. Quaternary Science Reviews 14, 959-966.

Kilian, M.R., van Geel, B., van der Plicht, J., 2000. ${ }^{14} \mathrm{C}$ AMS wiggle matching of raised bog deposits and models of peat accumulation. Quaternary Science Reviews 19, 1011-1033.

Kuylenstierna, J.L., Rosqvist, G.C., Holmlund, P., 1996. Late-Holocene glacier variations in the Cordillera Darwin, Tierra del Fuego, Chile. The Holocene 6, 353-358.

Luckman, B.H., Villalba, R., 2001. Assessing the synchroneity of glacier fluctuations in the western cordillera of the Americas during the last millennium. In: Markgraf, V. (Ed.), Interhemispheric Climate Linkages. Academic Press, San Diego, pp. 119-140.

Markgraf, V., 1983. Late and postglacial vegetational and paleoclimatic changes in subantarctic, temperate, and arid environments in Argentina. Palynology 7, 43-70.

Markgraf, V., 1993. Younger Dryas in southernmost South America-an update. Quaternary Science Reviews 12, 351-355.

Markgraf, V., D’Antoni, H., 1978. Pollen Flora of Argentina. Univ. of Arizona Press, Tucson.

Mauquoy, D., Engelkes, T., Groot, M.H.M., Markesteijn, F., Oudejans, M.G., van der Plicht, J., van Geel, B., 2002. High-resolution records of late Holocene climate change and carbon accumulation in two northwest European ombrotrophic peat bogs. Palaeogeography, Palaeoclimatology, Palaeoecology 186, 275-310.

McCulloch, R.D., Davies, S.J., 2001. Late-Glacial and Holocene palaeoenvironmental change in the central Strait of Magellan, southern Patagonia. Palaeogeography, Palaeoclimatology, Palaeoecology 173, $143-173$.

Mook, W.G., 1986. Recommendations/resolutions adopted by the Twelfth International Radiocarbon Conference. Radiocarbon 28, 799.

Pals, J.P., van Geel, B., Delfos, A., 1980. Paleoecological studies in the Klokkeweel bog near Hoogkarspel (Noord Holland). Review of Palaeobotany $30,371-418$.

Pendall, E., Markgraf, V., White, J.W.C., Dreier, M., 2001. Multiproxy record of late Pleistocene-Holocene climate and vegetation changes from a peat bog in Patagonia. Quaternary Research 55, $168-178$.

Quattrocchio, M.E., Borromei, A.M., 1998. Paleovegetational and paleoclimatic changes during the late Quaternary in southwestern Buenos Aires Province and southern Tierra del Fuego (Argentina). Palynology $22,67-82$

Rabassa, J., Coronato, A., Bujalesky, G., Salemme, M., Roig, C., Meglioli, A., Heusser, C., Gorillo, S., Roig, F., Borromei, A., Quattrocchio, M., 2000. Quaternary of Tierra del Fuego, Southernmost South America: an updated review. Quaternary International 68-71, 217-240.

Roig Jr., F., Roig, C., Rabassa, J., Boninsegna, J., 1996. Fuegian floating tree-ring chronology from subfossil Nothofagus wood. The Holocene 6, $469-476$

Speranza, A., van der Plicht, J., van Geel, B., 2000. Improving the time control of the Subboreal/Subatlantic transition in a Czech peat sequence by ${ }^{14} \mathrm{C}$ wiggle-matching. Quaternary Science Reviews 19 , $1589-1604$.

Stockmarr, J., 1971. Tablets with spores used in absolute pollen analysis. Pollen et Spores 13, 615-621.

Stuiver, M., Reimer, P.J., Bard, E., Beck, J.W., Burr, G.S., Hughen, K.A., Kromer, B., McCormac, F.G., van der Plicht, J., Spurk, M., 1998. INTCAL98 Radiocarbon age calibration, 24,000-0 cal BP. Radiocarbon $40,1041-1083$.

van Geel, B., 1972. Palynology of a section from the raised peat bog "Wietmarscher Moor" with special reference to fungal remains. Acta Botanica Neerlandica 21, 261-284.

van Geel, B., 1978. A palaeoecological study of Holocene peat bog sections in Germany and the Netherlands, based on the analyses of pollen, spores and macro- and microscopic remains of fungi, algae, cormophytes and animals. Review of Palaeobotany and Palynology $25,1-120$ 
van Geel, B., Mook, W.G., 1989. High resolution ${ }^{14} \mathrm{C}$ dating of organic deposits using natural atmospheric ${ }^{14} \mathrm{C}$ variations. Radiocarbon 31 , $151-155$.

Villalba, R., 1990. Climatic fluctuations in Northern Patagonia in the last 1000 years as inferred from tree-ring records. Quaternary Research 34, $346-360$.
Villalba, R., 1994. Tree-ring and glacial evidence for the Medieval Warm Epoch and the 'Little Ice Age' in southern South America. Climatic Change 26, 183-197.

White, J.W.C., Ciais, P., Figge, R.A., Kenny, R., Markgraf, V., 1994. A high-resolution record of atmospheric $\mathrm{CO}_{2}$ content from carbon isotopes in peat. Nature $367,153-156$. 